\title{
Budget division disputed
}

\section{Washington}

THE long-standing and sometimes heated debate over whether the US government spends too much of its biomedical budget on AIDS continues to split researchers into two almost equally large camps, according to the results of a survey released last week by the US Office of Technology Assessment (OTA). But regardless of their views on the budget shareout, most researchers agree that the assault on AIDS is leading to advances that spill over into other biomedical research fields.

Almost half (48 per cent) of the 148 people who responded to the survey "agreed or strongly agreed" that "too much research funding has been diverted to AIDS research from other fields", while almost as many (44 per cent) "disagreed or strongly disagreed" with the statement. Although the majority of those who strongly agreed with the statement were not receiving funds for AIDS research, more than 40 per cent of AIDS researchers also agreed with it.

Government funding for the study of AIDS has soared since AIDS was first diagnosed in the United States. The total budget now stands at almost $\$ 3,000$ million and the National Institutes of Health this year will spend about 10 per cent of its $\$ 7,100$ million budget on AIDSrelated projects.

Although the pace of budget increases seems set to slow, with the Bush administration requesting only a 7 per cent increase in the AIDS budget for 1991, funding for research on AIDS already exceeds that for heart disease and rivals that for cancer, despite the greater number of deaths from those diseases.

Critics of the high level of AIDS funding have been particularly scathing about the practice adopted by some agencies of actually requesting AIDS-related grant proposals when they feel they are receiving an insufficient number of them. This practice can lead to funds being siphoned away from the pool available for unsolicited grant proposals of higher quality.

Yet the dominant sentiment of the OTA survey is not that AIDS spending should be cut - nearly three-quarters of researchers felt that federal spending on AIDS was about right or even too low. Anthony Fauci, director of the National Institiute of Allergy and Infectious Diseases, believes that the message of the OTA report is that more money should be spent on biomedical research in general. "Rather than being concerned about making the slice of the pie for AIDS so big, perhaps the pie itself should be increased", he says.

Fauci also contends that the benefits of AIDS research have "transcended inter- disciplinary lines", a view endorsed by the OTA survey. More than half its respondents thought that AIDS research had led to substantial advances in fields such as virology, immunology and molecular biology, and more than one-third felt that AIDS research had "contributed substantially" to advances in diagnostics and drug development. On the other hand, genetics, pathology and biochemistry were frequently cited in the survey as having received "little to no" contributions from AIDS research.

At least 40 per cent of survey respon- dents thought that AIDS research had led to advances in a broad range of medical disciplines including oncology, neurology, haematology and pulmonary medicine, and to a better understanding of dementia and multiple sclerosis.

Last year, Congress made the first moves towards developing a more flexible system of funding for AIDS research. The appropriations committee responsible for the National Institutes of Health budget gave institute directors the power to shift money earmarked for AIDS research to other fields, as and when they consider it advantageous to do so. And according to Fauci, the extra flexibility is already producing research dividends. David Concar

\section{Helping Eastern Europe}

\section{London}

THE fledgling democracies of Eastern Europe are not able to absorb the massive financial aid packages being prepared by Western nations, according to the annual survey for 1989-90 of the United Nations Economic Commission for Europe (UNECE), released last week. The team of European economists, headed by Aleksander Vacic, a Yugoslav, says that aid should first concentrate on building the basic infrastructure of a competitive market economy, if financial grants and technology transfer to the East are not to be wasted.

There are many similarities between Eastern Europe's economic problems and those of the shattered post-war Western European economies. But a re-run of the 1948 'Marshall plan', when the United States injected cash into Western Europe, would not work, the report argues, because "the certainties of the central planning system have been eroded more quickly than the alternative mechanisms of the market can be put into place".

Ray Oakey, from Heriot-Watt University in Edinburgh, who is studying the diffusion of technology into the Hungarian economy, agrees with the UNECE analysis. He believes that Eastern European research institutes present a pool of cheap but high-quality scientific research labour waiting to be tapped by Western European industry. But the freedom from market pressures in the institutes over the past 40 years presents a problem. Even industrial research contracts, from state-owned manufacturing concerns, have often been little more than a "back door method of subsidizing research institutes", Oakey says. Until market pressures are brought to bear, it is difficult for prospective investors to gauge institutes' potential as centres for marketled research.

Oakey believes that the 'Know How Funds', run jointly by the British Foreign
Office and the Overseas Development Administration, could be used to promote joint ventures between British companies and Eastern European research institutes. These funds are to form the backbone of British assistance to Eastern Europe, but so far have been used mainly for training schemes in the financial sector. British companies may need more encouragement than most to invest in Eastern Europe, because Britain lacks the historical and ethnic links with Eastern Europe of countries such as West Germany.

Despite its cautionary tone, the UNECE report does suggest some areas where immediate financial aid to Eastern Europe is needed. Environmental pollution is a pressing problem (see Nature 344, $91 \& 610 ; 8$ March \& 12 April 1990) and transport and telecommunications systems need updating to Western standards.

Environmental improvement projects have not yet formed a major part of planned multinational aid packages. The European Communities' PHAR programme of aid to Poland and Hungary (which should extend to other East European countries soon), amounting to 300 million ECU in 1990, included no environmental schemes in the first round of projects approved in February.

But the European Communities (EC) environment ministers, meeting in Ireland last weekend, agreed in principle to a specific package of aid to help counter the massive environmental problems in the East. A formal outline for the programme will be drawn up at a meeting between EC and East European ministers in Dublin on 16 June. The transfer of cleaner Western industrial technology should be a major thrust.

EC ministers also suggested an environmental code of conduct for EC-based industries moving into Eastern Europe: industries must not be able to sidestep strict EC pollution controls by exporting pollution to the East.

Peter Aldhous 